THE RELIGION OF THE ETRUSCANS 
THIS PAGE INTENTIONALLY LEFT BLANK 


\section{THE RELIGION OF THE ETRUSCANS}

Nancy Thomson de Grummond and

Erika Simon, Editors

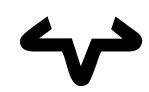

University of Texas Press Austin 
Selections from volumes in the Loeb Classical Library ${ }^{\circledR}$ are reprinted in Appendix B (p. 191). The Loeb Classical Library ${ }^{\circledR}$ is a registered trademark of the President and Fellows of Harvard College.

Copyright $\odot 2006$ by the University of Texas Press All rights reserved

Printed in the United States of America

First edition, 2006

Requests for permission to reproduce material from this work should be sent to:

Permissions

University of Texas Press

P.O. Box 7819

Austin, TX 78713-7819

www.utexas.edu/utpress/about/bpermission.html

(@) The paper used in this book meets the minimum requirements of ANSI/NIsO Z39.48-1992 (R1997)

(Permanence of Paper).

Library of Congress Cataloging-in-Publication Data

The religion of the Etruscans / Nancy Thomson de Grummond and Erika Simon, editors. - 1st ed.

p. $\quad \mathrm{cm}$.

Includes bibliographical references and index.

ISBN 0-292-70687-1 (cloth : alk. paper)

1. Etruscans - Religion-Congresses. I. De Grummond, Nancy Thomson. II. Simon, Erika.

BL740.R45 2006

$299^{\prime} .9294-\mathrm{dc} 22$

2005022652 